\title{
Debate historiográfico argentino e a construção da questão indígena
}

Ivia Minelli $^{1}$

Resumo: O objetivo deste artigo é apresentar a construção da representação indígena no pensamento argentino. A partir de um recorte dos anos 1960 até os dias atuais, propõese a mapear as transformações e as permanências argumentativas que estudiosos do tema evidenciaram no resgate desse ser autóctone, tanto em relação às balizas teóricas remanescentes dos discursos independentistas do século XIX, quanto aos diálogos estabelecidos nas últimas décadas que buscaram exaltar um ente esquecido pela história nacional. Foram, para isso, concentradas três categorias discursivas sobre o indígena: o índio vítima, o derrotado e o a-histórico. Acredita-se que o trato dado à história indígena na Argentina se configura mediante a presença de uma cultura política que permeia o pensamento histórico do país, revelando o poder argumentativo do imaginário pós-independentista e a forte significação da sociedade criolla para os séculos conseguintes.

Palavras-chave: indígenas, história política, sociedade criolla.

Abstract: The aim of this paper is to demonstrate the creation of the indigenous representation in the Argentinean national vision. Through a time limit from de 1960's until nowadays, we established the current argumentative changes and permanences that some scholars had shown throughout the recovering of this autochthonous figure in relation to two theoretical positions: the 19th remaining independents speech, and the last decades debates that sought the elevation of a forgotten entity in national History. Three are the speeches categories that we established here: the native as a victim, beaten and as a non-historical character. We believe that the indigenous History in Argentina is configured by the existence of a certain political culture that pervades the nation's historical sense, what reveals the argumentative strength acquired by the postindependent vision.

Keywords: Argentinean natives, political History, criollo's society.

\footnotetext{
${ }^{1}$ Mestranda em História na UNICAMP, com o projeto "Sarmiento e Hernández em diálogo: o universo da literatura gauchesca e o embate dos saberes no século XIX argentino", com financiamento do CNPq. Endereço eletrônico: iviaminelli@gmail.com.
} 
Para introduzir o debate acerca do legado indígena na historiografia argentina faz-se necessário mapear e definir, dentre o rol de autores escolhidos, algumas das principais abordagens que norteiam a representação desse ser autóctone na história do país. Três são os eixos aqui destacados que, de certa forma, circundam a maioria das obras a serem trabalhadas: a síntese de uma história indígena sob a égide da vitimação sofrida pelos índios, desprezados no decorrer da conformação da história nacional; a determinação do indígena como um derrotado na história republicana argentina, sucumbido mediante as imposições criollas; e a transposição de um arcabouço explicativo criollo ao indígena com o intuito de revelar sua presença no território e seu envolvimento com os processos independentistas, cedendo-lhe um caráter a-histórico.

Esse caminho de aproximação ao tema, que se tornou também uma constatação fundamental, é resultado de uma abertura mais complexa às análises sobre a organização do pensamento histórico argentino em relação ao indígena no século XIX, uma vez que as fontes bibliográficas utilizadas - situadas entre a segunda metade do século XX até o século XXI — suscitam debates que ultrapassam as problemáticas próprias da produção historiográfica, devido às suas origens e conteúdos diversos. Estudos de historiadores, antropólogos, sociólogos e etno-historiadores mesclam-se diante do esforço de definir o lugar do indígena na Argentina, evidenciando a história dos colonizados. A percepção desse intenso diálogo interdisciplinar inviabilizou uma disposição cronológica dentre os três eixos selecionados, já que a persistência dos atributos culturais associados aos indígenas não se revelaram prontamente substituíveis pelas inovações metodológicas, apresentaram, inclusive, diferentes relações e durações dentro de cada disciplina. Cabe a nós encontrarmos os cruzamentos desses estudos, contextualizando os debates e as evidências argumentativas. Segundo John Monteiro (2002, p. 6), muitas vezes, problemáticas oitocentistas são transpostas para os estudos atuais de forma a confirmar as imagens fossilizadas que os indígenas receberam dentro da sociedade, relegando a figura do índio ao manejo de uma história nacional criolla, no caso argentino.

Nesse sentido, chamaremos de "historiográfico" o debate que essa vasta bibliografia apresenta por conta dos movimentos temporais perseguidos em nosso estudo. Enfocaremos, pois, a relação do trato indígena dessa documentação com a 
perspectiva enraizada no próprio século XIX, estabelecendo como linha de análise, entre os eixos destacados, o discurso evidentemente político que percorre o pensamento histórico argentino. Para Roy Hora e Javier Trimboli (1994, p. 11), em livro que reúnem entrevistas com renomados historiadores argentinos da atualidade, em especial, nos anos 1960 e 1970, a detenção do saber histórico estaria relacionada a uma intrínseca capacidade de realizar uma política crítica, sendo a história vista como espaço alternativo de satisfação tanto profissional quanto pessoal. ${ }^{2}$ Até mesmo com as mudanças sofridas pela historiografia nos anos 1980 — decorrentes da decepção com os rumos democráticos do país, da profissionalização da disciplina a partir do surgimento da Academia, e da perda da posição hegemônica da história social com a incorporação de novos objetos e problemáticas culturais - Hilda Sabato (2001, p. 41-42) vai defender o lugar do fazer histórico antes de se propor a pensar na função desse fazer. $\mathrm{O}$ que os autores indicam é a dinâmica de uma historiografia que se relaciona prontamente com a sua história nacional, marcada por intensos debates políticos seculares que permeariam o esboço dos demais aspectos da sociedade, como, por exemplo, a cultura e os indígenas. Assim, afirmações como a de Beatriz Sarlo (HORA; TRIMBOLI, 1994, p. 174), sobre a impossibilidade de pensar algo em seu país que não passe pelo crivo da política, poderiam soar como desabafo, mas acabam se revelando uma postura teóricoargumentativa: "Yo creo en la política, en la especificidad de la política, en la política como profesión, y por supuesto en las nuevas formas de hacer política" (HORA; TRIMBOLI, 1994, p. 190).

Essa problemática política também foi alvo das observações de Juan Manuel Palacio (2002, p. 39), que aponta uma ausência temática fundamental na formação do pensamento argentino: a perspectiva latino-americana teria sido abandonada nas últimas décadas. $\mathrm{O}$ autor sugere que tal obsessão pelo recontar da história nacional fica evidente na própria renovação historiográfica que se deu na década de 1980 a partir da qual se discutem as teorias gerais de funcionamento do sistema latino-americano com base na noção de que

\footnotetext{
${ }^{2}$ A fim de não limitar essa relação entre política e o pensamento nacional argentino ao contexto contestatório de Ditadura Militar vivido pelo país em torno dos anos 1970, Hora e Trimboli defendem que a própria experiência historiográfica deveria ser entendida como experiência política, refutando interpretações que geralmente a reduzem a questões meramente estéticas ou profissionais. HORA, Roy; TRIMBOLI, Javier. Introducción: dos palabras al lector. In: Pensar la Argentina. Los historiadores hablan de historia y política. Buenos Aires: El Cielo por Asalto, 1994, p. 14.
} 
(...) refugiarse en lo nacional garantizaba a los historiadores un lugar seguro desde donde poder discutir - paso a paso, a través de monografías y estudios de caso, es decir, con las armas propias de la disciplina - las inexactitudes de aquellas imágenes de conjunto (PALACIO, 2002, p. 39).

Desmembrar-se de uma unidade latino-americana originaria uma problemática histórica para o país, que, na verdade, seria a confirmação de um antigo preceito: a excepcionalidade da postura argentina ante o restante do subcontinente (PALACIO, 2002 , p. 40). É possível notar que a grande temática civilizacional desenvolvida ao longo do século XIX, marcada por político-intelectuais pós-independentistas que buscam criar universos simbólicos autônomos na reinvenção de um eu latino-americano através de discursos hegemônicos (PRATT, 1999, p. 301), continua corroendo a memória histórica da Argentina, que revigora constantemente, em seus debates, conceitos oitocentistas enraizados. Assim, questões como Estado, povo e progresso acabam adquirindo um estatuto tautológico. ${ }^{3}$

Se parte significativa dos estudos argentinos baseia-se em uma temática nacional encabeçada por motivos exteriorizados pelo século XIX, a questão indígena está sob dupla problemática. A primeira seria de ordem temporal: uma vez rechaçado o momento histórico colonial em prol de uma discussão das heranças independentistas, a situação indígena passa a fazer parte de um passado pouco revisitado em que nada parece ter a contribuir ao processo de civilização de um país. O segundo problema seria teórico, pois, como decorrência da proposição anterior, o tema essencialmente político restringe o indígena a uma questão da própria sociedade oitocentista, e a exclusão desse elemento bárbaro, por exemplo, seria posta a mercê de um objetivo político. A política áurea lega ao indígena um lugar interpretativo estanque no imaginário argentino constituído sob bases civilizadas e hegemônicas, negando-lhe um espaço de autonomia discursiva indicadora de possíveis fissuras político-culturais. Embora possam ser identificados interrogantes distintos nos debates historiográficos, que acabam por deslocar a figura do índio vitimado para o de incorporado socialmente, os preceitos sobre ele não se abalam, pois a preocupação gira em torno de uma ideia de

\footnotetext{
${ }^{3}$ Essa questão tautológica é bastante explorada por Mauricio Tenorio Trillo no livro Argucias de la historia: siglo XIX, cultura y América Latina, no qual interpreta, para a Argentina, o estabelecimento de uma linguagem política que contataria dois séculos, dois mundos. Ver: TRILLO, M. T. Argucias de la historia... México: Ed. Paidós, 1999, p. 98.
} 
modernização, cujo objetivo não seria o de buscar traços arcaicos ou pensamentos genuínos no próprio país, mas inserir a Argentina no processo civilizatório ocidental dos séculos XIX e XX (SABATO, 2001, p. 44-45).

Segundo a análise sobre o pensamento político moderno de Hannah Arendt (1993, p. 42), a compreensão do universo que nos circunda seria anterior ao acesso do conhecimento, e, por isso, os preconceitos que antecedem uma investigação científica teriam seus espaços privilegiados. A partir dessa postura, evidencia-se o apreço histórico na Argentina de um personagem que tange, a todo momento, nosso recorte: o gaucho, responsável por sintetizar a complexidade da história nacional, tensionada entre as experiências citadinas e campestres que revolucionaram as noções de civilização e barbárie do país no século XIX. Essa figura emblemática e caricata carrega em si o fardo de refletir os meios impostos ao país para o alcance do progresso, tornando inexpressiva a presença de outros atores, como os próprios indígenas. ${ }^{4}$

Mediante a exposição sobre o estreito laço entre política e história na Argentina, indicamos vários autores em diálogo constante com tais tendências: alguns argentinos bastante renomados, como Tulio Halperin Donghi, David Viñas, Gabriela Montaldo, Pedro Navarro Floria, e outros estrangeiros, como Mónica Quijada, François-Xavier Guerra, Gabriel Passetti, que apresentam, em parte de seus estudos, uma aproximação, tanto temática quanto teórica, dos preceitos anteriormente citados. Vale ressaltar a nossa intenção de expor a trama argumentativa de cada autor e o debate historiográfico no qual se insere, com o objetivo de apontar, paulatinamente, as questões de conteúdo e abordagem que definiram o lugar do indígena.

\section{O indígena como vítima da sociedade criolla oitocentista}

Uma das mais recorrentes evidências historiográficas sobre o indígena, resistente ao tempo e às novidades da disciplina histórica, é entendê-lo como vítima de uma

\footnotetext{
${ }^{4}$ Eis o motivo pelo qual propusemos um recorte de trabalho dos anos 1960 em diante, tendo como finalidade contemplar os esforços de inserir esse ente esquecido nos estudos historiográficos. Essa opção de pesquisa se deu pela constatação de que os textos anteriores a esse período estariam em busca de discutir sobre o "ser nacional", como podemos indicar, a título de exemplo, Ruben Franklin Mayer e sua obra El país que se busca a sí mismo: historia social argentina. Nesse texto, Mayer tem uma abordagem bastante nacionalista, e, ao tentar estabelecer no gaucho o tipo ideal argentino, procura recuperar a verdadeira argentinidade esquecida. Ver: MAYER, R. F.El país que se busca a sí mismo... (1944). Buenos Aires: Editorial Claridad, 1970.
} 
sociedade que, atenta apenas aos anseios desenvolvimentistas, o teria confinado à marginalidade política, cultural e social. Os extermínios físicos realizados ao longo do século XIX na Argentina, iniciados pelos intuitos políticos de Juan Manuel Rosas em 1833 e culminados com a Conquista do Deserto de Julio Roca em 1879, foram interpretados a partir da fragilidade e inocência indígenas enraizadas no seu próprio modo de vida, pouco correspondente às propostas modernizadoras. Dessa forma, embora nenhuma corrente historiográfica tenha ignorado a questão da ausência indígena no país, devido ao evidente arrefecimento dos povos sulistas, a busca desses incomensuráveis, abertos e misteriosos ares do pampa (FLORIA; BELSUNCE, 1988, p. 50) geraria as mais diversas interpretações e explicações historiográficas, que muitas vezes consideraram a falta de protagonismo desse indígena como um fato, sem avaliar o processo histórico que lhe teria legado tal estatuto.

Em obra que confere a preponderância da cidade como personagem principal na condução do rumo histórico no século XIX, América Latina: as cidades e as ideias, o historiador argentino José Luis Romero define que o mundo rural, historicamente mais estável em suas conformações, desempenhava papel subserviente às cidades latinoamericanas, conforme suas mudanças ao longo dos séculos e consequentes exigências de adaptação (ROMERO, 2004, p. 42). Sendo o universo rural o do indígena, este estaria submetido às vontades e necessidades das aristocracias emergentes desde o período da colonização, pois "o conquistador necessitava dos indígenas dominados, ou melhor dizendo, subjugados e, ao mesmo tempo, benevolentes" (ROMERO, 2004, p. 81). E por preconceito, segundo Romero (p. 43-44), acreditou-se que o campo, visto como um aglomerado de territórios vazios, estava apto a ser incorporado ao sistema cultural colonizador.

Para o autor, este teria sido o legado colonial para as novas cidades do fim do século XVIII, fortalecidas pelas ações de independência no início do século seguinte: a sobrevivência do campo na história latino-americana, que significava também a manutenção da presença indígena, que impunha, por sua vez, entraves ao progresso das cidades (ROMERO, 2004, p. 159). Com as independências, as incipientes cidades 5 teriam como desafio desarticular as antigas relações com a sociedade rural a fim de

\footnotetext{
${ }^{5}$ Percebemos que nessa abordagem proposta por Luis Romero há uma tendência em generalizar a postura que os diferentes países tomaram em relação ao indígena. Embora Romero considere alguns particularismos nas construções das cidades, o olhar que teriam lançado sobre o campo seria o mesmo.
} 
tomarem as rédeas da ruralização no país, deixando a marca da presença criolla na constituição de uma economia forte (ROMERO, 2004, p. 161). Na interpretação de Romero, aos indígenas não haveria outra opção senão se inserirem nessa nova lógica criolla de expansão e controle territorial, devido ao estado de natureza de sua cultura ante a força dos anseios econômicos da elite. O campo teria sido historicamente um lugar impelido a aceitar os projetos de grupos citadinos que, por necessitarem desse espaço rural, rapidamente lhe impunham seus valores e motivos: "Negros, mulatos, índios e mestiços atenderam ao chamado e aderiram aos exércitos da independência" (ROMERO, 2004, p.219). Portanto, tudo estaria por fazer e o mundo rural tornava-se um problema criollo do século XIX independente.

A vitimação dos indígenas se estabelece na obra a partir dessa subordinação passiva a que eles estariam sujeitos, como se sua sorte estivesse atrelada à ação de terceiros, o que lhes impossibilitava qualquer autonomia discursiva. Entendendo por "vítima", dentre as derivações do sentido conferido cotidianamente à palavra, uma pessoa afetada de forma traumática, sujeita a arbitrariedades de outra, Romero esforçase por definir a mazela da vivência indígena nas atribuições criollas, que dominavam e determinavam seu espaço de atuação. O primeiro problema nessa análise está na simplificação das relações entre campo e cidade, inseridas numa lógica binária econômica que pouco revela sobre as dinâmicas sociais e culturais de sociedades latinoamericanas em profundas transformações. ${ }^{6}$ Assim como na aceitação dos discursos produzidos pela cidade como reflexos da realidade; ignora-se, por exemplo, que frisar a sujeição indígena angariaria um estatuto vitorioso aos projetos progressistas no século XIX, sendo este o mote principal do pensamento político argentino. Incorporá-lo como "vítima" é, portanto, a forma encontrada por Romero de oferecer continuidade e visibilidade a um debate eminentemente criollo e oitocentista, que revigora a origem nacional argentina nas propostas republicanas.

Em segundo lugar, o autor impõe características ao índio imbuídas de juízos de valor, como ignorante, frágil, incapaz, entre outras, simplesmente por não o encarar como um personagem histórico. $\mathrm{O}$ índio estaria à parte do cenário onde se desenrolavam

\footnotetext{
${ }^{6} \mathrm{Na}$ apresentação do livro de José Romero, edição brasileira aqui usada, Afonso Carlos Marques dos Santos indica o cunho marxista existente na obra, mas também mostra a importância de ter iniciado um debate de base latino-americana, pouco comum nos anos 1960-70, ainda que utilizasse balizas europeias de análise.
} 
a história e as tramas independentistas de um país em construção, sendo apático às mudanças e aos rumos tomados pelos criollos, justificaria, assim, os motivos genocidas, físicos e culturais, que o levariam à desagregação social. Por essa razão, entendemos como necessária uma leitura do indígena não a partir da história contada pelo século XIX, mas do próprio ato de contar, de "fazer história", sobre esse século, pois “(...) sem dúvida a história é o nosso mito; ela combina o 'pensável' e a origem, de acordo com o modo através do qual uma sociedade se compreende" (DE CERTEAU, 2006, p. 33).

Para Michel de Certeau, existe uma série infinita de "sentidos históricos" estabelecidos nos discursos do historiador, que precisa lidar com a compreensão do "real" que lhe é próprio e de um "real" implicado pela sociedade em estudo (DE CERTEAU, 2006, p. 45).

A interpretação sobre os determinismos da cidade no campo, fortemente marcada por uma abordagem restrita a prerrogativas econômicas e políticas, também está consagrada na obra Proyecto y construcción de una nación (1846-1880), de autoria de Tulio Halperín Donghi, que dispôs os eventos históricos do século XIX como decorrências de interesses administrativos e militares, subjugando o indígena e seu habitat às ambições do poder político, que, muitas vezes, teria encontrado na própria defesa dos povos originários uma estratégia política para angariar riquezas das fronteiras (HALPERÍN DONGHI, 1985, p. 88). Com o intuito de realizar um balanço geral dos processos políticos sofridos pelo país a partir dos projetos de Domingo F. Sarmiento e Juan B. Alberdi ${ }^{7}$, nessa obra, o indígena seria apenas significado no rol dessas ações políticas, o que também definiria sua história como resultado de interesses citadinos. "No es sorprendente que un sistema de defensa que se basa en la arbitrariedad administrativa para movilizar los recursos humanos que requiere, acentúe el imperio de ésta sobre las zonas en que recluta sus víctimas.” (HALPERÍN DONGHI, 1985, p. 88).

A forma como Halperín Donghi encara o índio acaba por empobrecer um estudo sobre o tema porque pressupõe a ausência da autonomia indígena como um fato dado, a ponto de apresentar o genocídio de 1879 como o fim da história indígena na Argentina:

\footnotetext{
${ }^{7}$ Esses dois autores e seus escritos clássicos — Alberdi (1810-1884) com Bases y puntos de partida para la organización política de la República Argentina (1852) e Sarmiento (1811-1888) com Facundo: civilización y barbarie (1845) — consolidam projetos autônomos de um país que pensaria, discutiria e sustentaria seu próprio desenvolvimento.
} 
“(...) esa presencia que había acompañado la entera historia española e independiente de las comarcas platenses se desvanecía por fin" (1985, p. 100).

Entre táticas e práticas, o índio teria sido mera peça política da sociedade criolla, passível de descarte nos anos 1880, momento em que os processos de construção nacional passariam a enfrentar problemas de insegurança quanto à liberdade e à igualdade alcançadas com a consolidação republicana. O passado da colonização estava superado, morria o indígena e ficava por ser discutido o avanço cego e avassalador da ordem capitalista que se sobrepujava pelo planeta (HALPERÍN DONGHI, 1985, p. 101).

Halperín Donghi explica que essa postura indígena, que teria determinado seu fim, esteve definida, em solo americano, no contato com a sociedade desenvolvida, a começar pela herança de práticas espanholas no trato com as fronteiras indígenas, como, por exemplo, a manutenção de tropas de defesa nos arredores de Buenos Aires dispondo da violência para o controle fronteiriço ( 1985, p. 87). Assim, o autor define na vitimação do índio a fatualidade do seu pesar, já que o reputava detentor de uma cultura que sucumbiria invariavelmente ante a ação política de uma sociedade mais civilizada.

Essa produção histórica nos revela, em sua matriz dicotômica, uma chave interpretativa que, buscando frisar a novidade encontrada pela sociedade oitocentista diante da necessidade de consolidar sua autonomia, define as formas como os preceitos civilizacionais europeus seriam incorporados pelos debates argentinos. Ou seja, o autor torna natural o objeto local em análise e, consequentemente, o trato oferecido ao indígena, como se essa atitude argentina fosse resultado de uma vontade universal (HALPERÍN DONGHI, 1985, p. 26). Uma postura crítica a tais estudos seria romper com esse frágil argumento estanque, ao proporcionar uma análise que não confundisse aspectos metodológicos com o objeto de estudo, conforme sugere Elias Palti (2006, p. 25), pois o predomínio de discussões políticas atuais não deveria conduzir a leitura de um passado que elaborou certo discurso político sobre o índio numa lógica específica de projeção nacional.

A preponderância dos discursos oitocentistas sobre a história da Argentina também pode ser sentida nos estudos de Nicolás Shumway, especialmente em La invención de la Argentina: historia de una idea, obra em que a excepcionalidade da política nacional do século XIX se destaca em relação ao continente, devido à

Revista Eletrônica da ANPHLAC, n.11, p. 105-140, jul./dez. 2011. http://revista.anphlac.org.br/index.php/revista 
capacidade de direcionar o caos até então implementado na região platina, assinalando uma autonomia resolvida e bastante próspera.

Tal era la Argentina durante la segunda mitad del siglo XVIII: una tierra de pueblos aislados, vecinos autonomistas, gauchos nómadas, estancieros con peones relativamente dóciles, indios sin dominar, mínimo desarrollo económico y político. Y ninguna idea de destino nacional (SHUMWAY, 1995, p. 29-30).

Shumway aponta que as distintas regiões do continente tinham liberdades de ações ante uma coroa espanhola sem rigor administrativo, o que, no caso argentino, evidenciava-se na supervalorização da prata peruana escoada sob o controle da cidade de Buenos Aires. Esse fato ajudaria a explicar a formação de uma Argentina baseada em localismos e personalismos (SHUMWAY, 1995, p. 20-23), que obteve uma solução administrativa através de "ficções orientadoras", representantes de um conjunto de tradições inventadas aglutinadoras do sentimento nacional e do destino histórico comum à nação ( p. 19).

Esse tipo de trabalho historiográfico foi analisado por Mauricio Tenorio Trillo como aquele que se deixa envolver pelas armadilhas de uma história nacional criada por pensadores do século XIX. Armadilhas que foram estabelecidas sob uma rede de argúcias, próprias de um período que teria aprendido a fazer do passado "la prudencia que necesitamos para 'otra vez', y la sabiduría que requerimos "para siempre'" (TRILLO, 1999, p. 147). O autor considera que o indígena, nesse momento de apropriação da natureza, recebeu duas conotações distintas na Argentina: por um lado, um sentido bucólico, de beleza e de riqueza selvagens, e, por outro, de barbárie, associada a um deserto que carregaria em si a luta constante de superação do passado pelo presente (TRILLO, 1999, p. 108-109). Dessa forma, a natureza não teria sido a atriz principal do século XIX latino-americano, deixando o espaço para a ciência e as letras como definidoras da nova cultura.

A análise de Shumway sobre a Argentina cai nessa armadilha ao explicar o caso do extermínio indígena no país através da necessidade de definir uma população homogênea, o que fatalmente excluiria o ser autóctone das ficções orientadoras, uma vez expressa a impossibilidade histórica local de fazê-lo entender e ser parte das práticas comuns da nova sociedade (TRILLO, 1999, p. 26-28). Ao consolidar o século 
XIX como o mote de sua perspectiva histórica, Shumway mostra que, mesmo o índio não tendo sido domado pela sociedade colonial, tal logro seria obtido pelo fortalecimento da política interna argentina. Ora, tal argumento vale-se de alguns teleologismos, combatidos por Trillo, para explicitar sua proposição: aponta o domínio sobre o indígena como uma conquista do período independentista, justificando sua ausência física e cultural no fortalecimento do gaucho. O índio seria, portanto, vítima da postura política do século XIX devido à sua insubordinação ante o povo criollo, que encontrou no gaucho uma importância ideológica, como se ele fosse o próprio espírito de uma nação adolescente (Trillo, 1999, p. 94). Novamente, discorre-se sobre o triunfo da cidade sobre a natureza, com uma leitura política que define índio a partir das escolhas de um mundo civilizado, transformando-o num “outro" sem lugar, sem voz e, por isso, sem história.

Na obra de David Viñas, Índios, ejército y fronteras, podemos apreender melhor essa situação do indígena em contraposição à do gaucho argentino, ao passo que resgatamos os artifícios de uma identidade nacional que ignora as escolhas de um passado que teriam determinado o extermínio indígena. Tomando a obra Martín Fierro como um dos aportes para seu estudo, o autor aponta dois tipos de representação discursiva literária que poderiam representar a vida social oitocentista: a do gaucho como consequência de uma infração episódica, e a do indígena, um conflito permanente (VIÑAS, 1982, p. 159). Nos versos do poema, o dilema vivido pelo gaucho é o da adequação a que está submetido pelos rumos históricos e civilizacionais do país, enquanto o indígena está entre a vida e a morte; sendo este a negação do branco, sua história e seu fim estariam na tragédia e os do gaucho, em um drama (VIÑAS, 1982, p. 160). A fim de organizar essas representações literárias sob uma perspectiva crítica, Viñas inicia seu livro com uma série de indagações que sintetizam a temática e os objetivos nele contidos (um conteúdo político que visa analisar o momento presente de seu país através de um estudo histórico comparativo): “¿Los historiadores dijeran algo de ese silencio? ¿Por qué no se fala del indígena? ¿No tenían voz los indios? ¿O su sexo era una enfermedad? ¿Y la enfermedad su silencio? (...) ¿Son los indígenas los desaparecidos de 1879?" (1982, p. 12).

$\mathrm{O}$ autor registra sua indignação em relação à falta de estudos sobre os indígenas no país, ao passo que percebe o mesmo movimento na ausência de investigação a

Revista Eletrônica da ANPHLAC, n.11, p. 105-140, jul./dez. 2011. http://revista.anphlac.org.br/index.php/revista 
respeito dos "desaparecidos" da ditadura argentina nos anos 1970. Dessa forma, sua pesquisa, focada em desvendar os atos governamentais que eliminaram a presença indígena no país, começando por definir o governo de Roca como clímax, como a execução de uma dramaturgia ensaiada ao longo do século XIX (VIÑAS, 1982, p. 20), recupera o elemento autóctone excluído, mas apenas na medida em que esse elemento ajudaria a refletir sobre as heranças políticas ainda em vigor na segunda metade do século XX.

Por conta das políticas desenvolvidas no final do século XX, relacionadas a um momento de crescente aproximação com o governo dos Estados Unidos, a conquista militar do deserto se apresentava como lúcida correlação aos eventos da "expansão para o Oeste" norte-americana, visto que essa visão inseriria a Argentina num contexto continental (VIÑAS, 1982, p. 14-15). Portanto, matar o indígena seria uma forma de apagar o membro duvidoso da sociedade, aquela "oveja negra que pone en suspenso la blanquitud de las blancas" (VIÑAS, 1982, p. 50). Para Viñas, a intenção de Roca seria acabar com os poderes locais, como o do importante cacique Calfucurá que, desde os anos 1840, dominava a região economicamente estratégica das grandes salinas (1982, p. 91-92). ${ }^{8}$ Essa presença cotidiana, que atrasava os interesses desenvolvimentistas do país, teria sido eliminada no momento em que a ameaça inimiga não poderia mais resumir-se aos indígenas, aos problemas internos, pois povos vizinhos ameaçavam avançar sobre as terras produtivas nacionais.

Podemos notar que todo o estudo de Viñas foi desenvolvido com a cautela de oferecer correlações entre vítimas seculares — índios e desaparecidos —, que estiveram subordinadas à presença de um Estado tirano militarizado que eliminava as oposições político-culturais, a fim de obter um desenvolvimento político-econômico a qualquer preço. Assim, dessa postura crítica de Viñas, resulta sua análise sobre a fonte escolhida para tal comparação: a literatura, como reflexo da realidade. Ao escolher um documento literário como fonte historiográfica, o autor deveria estabelecer alguns cuidados específicos no trato desse tipo de objeto, não pelos limites que o universo artístico da literatura lhe ofereceria, mas exatamente pelo inverso: o risco de enxergarmos, por

\footnotetext{
8 Habitat dos índios conhecidos como "infiéis", famosos por sua agressividade, complexidade e organização interna.
}

Revista Eletrônica da ANPHLAC, n.11, p. 105-140, jul./dez. 2011. http://revista.anphlac.org.br/index.php/revista 
fetiche documental, a literatura como reveladora de um mundo miniaturizado, cuja inteligibilidade fosse imediata (SARLO, 2005, p. 79-80).

Beatriz Sarlo, revisando as fronteiras que circunscreveriam o lugar da história, percebe que a busca por um discurso objetivador na fonte literária pode negar a especificidade artística desprendida de um texto e a densidade semântica de uma época, pela desconsideração das variáveis entre literatura, ideologia e referência (2005, p. 8283). Assim, notamos que a comparação de vitimação realizada por Viñas concretiza-se sob um duplo problema: delimitar o passado às leituras do presente e exatamente o seu revés, mantendo o discurso oitocentista vivo a fim de explicar um presente fugidio. Novamente o indígena é vítima, porque é resultado de uma política criolla do século XIX, política esta que se sustentaria a ponto de expandir sua tradição a outros espaços da sociedade argentina. Portanto, embora todo o livro de Viñas tenha como mote o índio, a personagem central continua sendo a política que o submetia.

Essas primeiras abordagens apresentadas sobre o indígena, depreendidas das obras de Romero, Donghi, Shumway e Viñas, trabalham com uma perspectiva determinista sobre a cultura, na medida em que a ela se atribui uma funcionalidade política. Esses estudos, que encontram na política a primeira forma identitária vivida no continente, nela sintetizam a ação agregadora de um imaginário coletivo definidor dos demais pressupostos de uma nação. As ideias de François-Xavier Guerra, sobre a formação das identidades nacionais na América Hispânica, podem estabelecer aqui uma ponte para explanarmos as posturas teóricas de tais autores: a especificidade da Argentina, assim como a dos demais países do continente, estaria em considerar a questão cultural como consequência da consolidação das políticas pós-independentistas:

En la Europa del siglo XIX se trata de cómo construir el Estado-nación a partir de la nacionalidad; en Hispano-América, de cómo construir Estadonaciones separados a partir de una nacionalidad en gran parte común a todos (GUERRA, 2003, p. 220).

Ao fazer-se singular ante a Espanha, surgiria a necessidade de constituir nações diferenciadas dentro da América, uma vez que suas características centrais, como a religião e o idioma, eram homogêneas, assim como suas próprias motivações políticas.

O problema dessa escolha de análise está em criar uma via de mão única entre política e cultura, que, ao mesmo tempo que valoriza as especificidades históricas

Revista Eletrônica da ANPHLAC, n.11, p. 105-140, jul./dez. 2011. http://revista.anphlac.org.br/index.php/revista 
locais, ignora a formação do pensamento político dentro das várias experiências seculares do continente. Se o índio sucumbe à memória histórica argentina, diferentemente dos mexicanos que o enaltecem, a questão deve ser posta nessa atribuição ao lugar indígena, e não apenas nas relações econômicas que o circunscreviam em cada região. ${ }^{9} \mathrm{Na}$ Argentina, em que o século XIX reclusa a história nacional basicamente às experiências vividas por Buenos Aires, o índio não era uma presença cotidiana e criou-se o mito de o país ser a "nação branca" da América Latina, fato este que muitas vezes é lido como uma simples escolha consciente de ação política.

Da mesma forma, a problemática indígena não deve ser estabelecida segundo os modelos civilizacionais europeus, mas nas tensões inerentes à Argentina, que sequer eliminou o índio dos debates jurídicos, da literatura e dos tratados políticos durante o século XIX. Não negamos aqui a importância que a lógica político-cultural europeia e norte-americana tiveram nesse momento fundador argentino, tendo em vista que o estabelecimento dessa correlação foi um dos motivos centrais na consolidação da autonomia política dos novos países (PRATT, 1999, p. 296-297). Apenas chamamos a atenção para a definição do lugar indígena como parte constitutiva da construção do pensamento argentino oitocentista, devendo ser agregado, inclusive, como um dos fundamentos chave de formação da cultura nacional.

\section{A incorporação cultural do indígena: a derrota cultural do elemento nativo}

O pensamento historiográfico que acima chamamos de "vitimação" tem sido bastante questionado por estudiosos da história argentina que se propõem a interpretar a problemática indígena segundo a história do país. Essa mudança foi introduzida pelas vertentes culturalistas em emergência na década de 1980, que buscavam alternativas às abordagens política e econômica como elementares para a escrita da história. Para Peter Burke, uma das principais contribuições dessa "virada cultural", sentida em vários países e continentes, foi a de deslocar o foco da "sociedade" para a "cultura", de forma a

\footnotetext{
${ }^{9}$ Segundo Guerra, Buenos Aires teria se apresentado num movimento de ruptura mais radical quanto à reivindicação de sua autonomia por não possuir vínculos coloniais tão bem definidos como o México e o Peru, por exemplo. Estes, chamados de "lealistas", devido à forte referência colonial em seus territórios, tiveram na marcante presença espanhola, inclusive, o motivo para a não desagregação territorial e, por isso, teriam tido a necessidade de enfatizar a especificidade indígena como símbolo da liberdade adquirida na independência. GUERRA, F. Las mutaciones de la identidad. In: GUERRA, François-Xavier (Coord.). Inventando la nación. México D. F.: FCE, 2003. p. 208-209.
} 
fragmentar os objetos de estudo e destacar as particularidades vividas por distintos grupos, em diferentes locais e épocas (BURKE, 2005, p. 8).

Sobre esse novo campo de argumentação reiteramos os termos do mexicano Trillo, ao interrogar o lugar assumido pelo termo "cultura" na América Latina, geralmente associado às histórias nacionais plurais que comporiam um todo continental. Essa postura determina que a América Latina seja, ela própria, uma história cultural, no sentido de absorver as noções de espaço e tempo historiáveis que rompessem com os marcos políticos sustentadores de uma homogeneidade local (TRILLO, 1999, p. 159).

Vale lembrar que na Argentina essa novidade teórica coincidiu com o período de redemocratização do país e da consequente volta da disciplina de história para a Academia, gestora de um dinamismo crítico ao "progressismo" e ao "universalismo", que tornaria mais complexa a história nacional ao sair dos debates políticos para enfocar a ação humana, retirando da política o tom de densidade única e específica do século em questão (SABATO, 2001, p. 46-47). Dessa forma, com a ênfase dos estudos culturais nas particularidades nacionais, emergentes de uma crise estruturalista e de suas determinantes temáticas (PALACIO, 2002, p. 38), o indígena começa a ter espaço como objeto e fonte de estudo na Argentina, não sendo estudado apenas como simples vítima política e econômica da sociedade criolla oitocentista. Enfocando elementos de caracterização nacional - como o território e os debates constitucionais para explorar, por exemplo, a áurea autônoma do país no século XIX —, a história argentina não mais poderia ignorar o indígena e seu contato com a sociedade criolla, muito menos desterrálo de seu lugar nos processos de construção nacional, como o fizeram ao colocá-lo numa posição ingênua e incapaz de compreender a lógica de dominação territorial vivenciada naquele momento (QUIJADA, 2004, p. 433).

Inserida nesse debate teórico sobre os indígenas, Mónica Quijada define algumas importantes linhas de estudo que colocam as novidades dos anos 1980 como um esforço de desconstruir o mito da nação branca na América Latina, tais como: pensar a diversidade e heterogeneidade indígena, a fim de compreender não apenas as sociedades nativas, mas as suas interações com as sociedades brancas; considerar as relações entre os próprios indígenas e os processos internos delas derivados, devido ao contato entre diferentes grupos pela cordilheira dos Andes; e valorizar os aspectos de sociabilidade indígena com referência a meios sociais, políticos e econômicos de suas organizações 
internas (2004, p. 427). No entanto, percebemos que essa abrangência do mundo indígena só aparece na história argentina na medida em que o foco se mantém na sociedade criolla, seja no explícito desejo de pensar esse contato seja nas intenções de conceder sentidos a distintas organizações sociais. Quijada compreende as relações históricas entre índios e criollos a partir de negociações e participações que recuperam "la presencia indígena en el contexto de las problemáticas pasadas y presentes del Estado argentino" (2004, p. 428).

Essa nova postura teórica, que não abandona os preceitos de uma história política, nem deixa de considerar a realidade indígena como uma situação imposta pela sociedade criolla, diferencia-se da anterior ao deslocar de "fora" para "dentro" o lugar do índio na história nacional; ou seja, dele é retirado o estatuto de vítima para colocar o de "derrotado", pois ele teria sido ausentado a partir de sua incorporação a uma sociedade que não o representava individualmente. Se antes ele era vítima pela exclusão — visão criticada porque legaria apenas morte física aos índios —, agora ele seria um derrotado devido à inclusão imposta pela cultura da sociedade criolla.

(...) defenderé la hipótesis de que no hubo exterminio físico (aunque la guerra produjera muertes, sea por violencia o enfermedad), sino un proceso de reclasificación facilitado por las condiciones de contacto fronterizo; y que este proceso de reclasificación se acompañó de un convencimiento colectivo de la desaparición del indio por el conflicto militar, que se desvirtuó de un eje fundamental de la construcción identitária nacional (QUIJADA, 2004, p. 428).

Do trecho acima, extraímos um dos elementos mais significativos na argumentação da autora: a incorporação da noção de território como a chave para compreender a unicidade da política e da cultura desenvolvidas no país. Fator que diferenciaria a história argentina pela ideia de que as fronteiras defendidas teriam sido historicamente criadas e não ocupadas (QUIJADA, 2000, p. 378). ${ }^{10}$ Quijada não considera a formação da Argentina pautada nas tradições evocativas do passado, mas no futuro, e, por isso, não poderia reivindicar a ascendência indígena como fonte de legitimação territorial, o que caracterizaria a vitória discursiva do passado sobre o presente (QUIJADA, 2004, p. 431). Dessa forma, o pertencimento ao território seria

${ }^{10}$ Isso implicaria na elaboração de um espaço de "deserto" interno, exuberante e único, em toda a América Hispânica, o qual deveria ser ocupado e civilizado segundo as referências buscadas no exterior — Europa e Estados Unidos. 
definido através da noção de "identidade cidadã", que representa os esforços políticos de solidificação de um sentimento coletivo, cuja abrangência alcançaria inclusive o indígena conquistado, visto que este teria o direito inalienável de identificação pela sua condição de nativo do território nacional (QUIJADA, 2000, p. 384).

Através do que ela chamou de "reclassificação", o indígena, ainda que fosse considerado um cidadão debilitado, perderia todos os seus aparatos de defesa cultural ao incorporar-se à sociedade majoritária, sendo despojado de sua cultura no processo de cidadania em pauta (QUIJADA, 2004, p. 431). Quijada mostra que essa proposta político-cultural, inicialmente aglutinadora, teria sido levada a cabo pelas ações militares da Conquista do Deserto, pois o extermínio físico justificava-se pela necessidade de construir um sentido final coletivo, que implicava a indispensável exclusão do elemento nativo (QUIJADA, 2003, p. 311-314). Nesse desfecho é que estaria concentrado o mito da "nação branca", a partir do entendimento de eliminação total da presença indígena, como se fosse um fim trágico derivado de uma necessidade (QUIJADA, 2004, p. 432).

A perspectiva de Quijada é instigante e bastante importante para nossas reflexões, tendo em vista que poucos são os trabalhos dedicados a uma revisão historiográfica sobre a figura indígena na Argentina. No entanto, apontamos como problema argumentativo essa tentativa centralizadora e persistente de pensar a ausência indígena como fruto de uma incorporação sociocultural de ordem política, o que leva a autora a evocar, no entendimento dessa possível construção coletiva, a correção de seus efeitos, propondo o estabelecimento de uma justiça histórica como parte de seu objetivo de análise (QUIJADA, 2004, p. 429). Tal postura nos leva a pensar que seus textos, antes de estabelecer uma preocupação histórica, propõem um diálogo com o presente da escrita e a atual realidade indígena ${ }^{11}$, o que acaba condicionando o debate a um plano de ação política criolla tutelar sobre o índio. Frisa-se, assim, uma "retórica da culpa" que reorganiza a argumentação entre vencedores e vencidos, sob a égide das grandes

\footnotetext{
${ }^{11}$ A autora mostra a preocupação com a atualidade ao revelar sua indignação, por exemplo, com as pesquisas oficias de censo na Argentina que, apenas em 2000, teriam reconhecido a presença de comunidades indígenas no território nacional. QUIJADA, M. De mitos nacionales, definiciones cívicas, y clasificaciones grupales. Los indígenas en la construcción nacional argentina, siglos XIX a XXI. In: ANSALDI, Waldo (Coord.). Calidoscopio latinoamericano: imágenes históricas para un debate vigente. Buenos Aires: Ariel, 2004. p. 426.
}

Revista Eletrônica da ANPHLAC, n.11, p. 105-140, jul./dez. 2011. http://revista.anphlac.org.br/index.php/revista 
matrizes explicativas com as quais também trabalhavam os autores da vitimação. ${ }^{12}$ Ao mesmo tempo que a autora sinaliza para um problema histórico, o define como uma questão social, exigindo do historiador uma atitude frente ao passado que, na sua visão, permaneceria latente.

Em busca das consequências do contato entre culturas díspares no século XIX, encontramos a obra Ficciones culturales y fábulas de identidad en América Latina, de Graciela Montaldo, cujo mote central também seria o de estabelecer a relação entre identidade e território nas consolidações de mitos nacionais (MONTALDO, 2004, p. 8). Sua abordagem torna-se diferente da apresentada por Quijada porque introduz a problemática da natureza como chave para a compreensão de um problema cultural e político, definindo o indígena como o representante desse mundo natural, e, por isso, em franco diálogo com a sociedade letrada criolla em formação. Para Montaldo, a atividade intelectual romântica do século XIX estaria toda ela envolta pela questão territorial, a ponto de a luta pelo espaço nacional assumir a forma da luta política de organização da nação (2004, p. 17).

A forma como a autora interpreta o diálogo cultural entre indígenas e criollos letrados vale-se de uma metodologia antropológica em diálogo com a história, devido à abertura dos estudos culturais que buscaram pensar a organização das sociedades fora da superestrutura (BURKE, 2005, p. 56). Montaldo interpreta os processos de nacionalização da cultura argentina na transculturação, isto é, no estabelecimento do “jogo de olhares" entre duas tradições, a local e a europeia, gerenciado por uma elite intelectual que não poderia negociar a europeização do país e, por isso, estaria incumbida de reconhecer a diferença $(2004$, p. 42-43). E, nesse jogo letrado, o indígena seria o bárbaro a ser excluído porque, embora a origem do termo "transculturação" sugira intercâmbios de valores entre duas ou várias culturas que culminam numa terceira manifestação cultural ${ }^{13}$, a autora define a sociedade criolla como mediadora da

\footnotetext{
12 Essa apreciação do trabalho de Quijada é resultado de uma leitura do texto de Edward Said, que, preocupado em tornar complexas as relações estabelecidas pelas experiências colonizadoras e imperialistas da Europa sobre outros continentes, questiona se, ao aceitar a "retórica da culpa", não estariam os historiadores resumindo a História a uma forma de denunciar o passado e, assim, reiterando justamente os discursos de dominação civilizacionais europeus. SAID, Edward. Territórios sobrepostos, histórias entrelaçadas. In: Cultura e imperialismo. São Paulo: Cia. das Letras, 1995. p. 50.

${ }^{13}$ Transculturação foi um termo cunhado originalmente pelo cubano Fernando Ortiz para definir os processos transformadores que a introdução do açúcar pelos espanhóis teria causado na cultura de Cuba, negando a simples ida e vinda de costumes entre duas distintas culturas, na medida em que deveria ser valorizado o impacto sofrido por elas nesse contato. ORTIZ, F. Contrapunteo Cubano del tabaco y el
} 
natureza primitiva indígena e da cultura europeia espelhada no continente (MONTALDO, 2004, p. 41).

Assim, novamente, o índio converte-se em derrotado por estar inserido nos trâmites da sociedade criolla, apresentando-se como "lo más real de la patria, la acechanza de una fuerza que puede devorar a todos y, en especial, al sujeto letrado que se propone revelar la verdad de la nación" (MONTALDO, 2004, p. 52). O mito de origem criolla não-indígena teria sido produzido por essa ocupação das letras na história do país, o que revelaria a literatura como máxima expressão da nacionalidade. Montaldo afirma que a exclusão do índio, da natureza, seria parte de uma definição subjetiva do território nacional, constructo de um esforço político suscitado por influências europeias, conforme nos apresenta através de sua leitura sobre Sarmiento:

\begin{abstract}
[Sarmiento] Va a afirmar por ello que 'nuestro Oriente es la Europa': es dice - nuestro archivo, la memoria de lo que no somos pero que tenemos que adaptar, pues es capaz de proporcionar la diferencia para constituir una identidad; en un sentido puramente territorial, Europa-Oriente es lo Otro, es el punto cardinal desde el cual pensarse. Fundamentalmente, esta afirmación significa declarar la occidentalidad de los americanos, cuando Occidente es el valor más positivo para definir una identidad. (...) De este modo, Sarmiento altera las fronteras para crear otra espacialización por la cual viajar: una espacialización que une no los puntos geográficos sino los "tiempos" de desarrollo de los diferentes pueblos (2004, p. 68).
\end{abstract}

Nessa interpretação, o índio seria um elemento marginalizado diante de uma cultura ocidentalizada, suprimido ante a adoção da Europa como o Oriente Hispanoamericano. Frisar essa relação da política argentina com o seu "oriente" foi a forma encontrada por Montaldo para delimitar as questões que também teriam embasado o século XIX, referentes à constituição de sua origem num passado propriamente europeu. No entanto, essa aproximação com o mundo ocidentalizado não deve ser entendida como o debate central no país, pois o lugar desse oriente, nos textos sarmientinos, dialogava com a barbárie que habitava os campos, expressa ora no gaucho, ora no índio selvagem. Sem dúvida, "ser ocidente" foi parte importante da preocupação política

azúcar. (1940).Venezuela: Biblioteca Ayacucho, 1987. p. 93. É interessante indicar, inclusive, o debate feito por Ángel Rama sobre a adaptação desse conceito para a análise de obras literárias, pois ele o relativiza ao afirmar que a literatura pressupõe em si critérios de invenção e seletividade, e que, portanto, deveria ser cautelosa a aplicação da ótica sociológica de Ortiz. RAMA, A. Transculturación narrativa en América Latina. (1982). México: Siglo XXI, 1985. p. 32-33.

Revista Eletrônica da ANPHLAC, n.11, p. 105-140, jul./dez. 2011. http://revista.anphlac.org.br/index.php/revista 
argentina, mas principalmente enquanto essa expectativa fosse útil para legitimar os projetos políticos nacionais.

Outro pesquisador em diálogo com essa perspectiva é Pedro Navarro Floria, autor de dois artigos que podem ser explorados em nossa discussão sobre os indígenas "derrotados", sobretudo, pela fonte escolhida — basicamente os diários de sessões do Congresso Nacional - e pelo tratamento que lhe é dado. Ao eleger essa documentação como forma de pensar o índio na Argentina, Navarro Floria sintetiza as balizas argumentativas oitocentistas nos debates políticos institucionalizados, atitude que possibilitou a investigação da paulatina domesticação discursiva e legal sobre o indígena, através de um processo constitutivo de sua selvageria (NAVARRO FLORIA, 2005, p. 2).

A partir do que o autor chamou de a "Segunda Conquista", referindo-se à segunda metade do século XIX, em que teriam sido desfeitas as referências coloniais com a afirmação de uma lógica republicana no país, haveria a definição do índio como um "selvagem" conforme o sentido político interessante à época, pois, quando a "civilização" passou a ser desejada como futuro incondicional para a Argentina, tornar o elemento nativo biologicamente inferior seria o meio de justificar um projeto político com a finalidade de exterminá-lo, escusando, inclusive, o uso da violência contra esse mal social (NAVARRO FLORIA, 2005, p. 7-8). A nova ordem política não incluiria os indígenas, que, para assumirem-se indivíduos nacionais, deveriam privar-se de qualquer direito coletivo, processo este chamado de domesticação, a partir da imposição de regras criollas (NAVARRO FLORIA, 2005, p. 24).

\footnotetext{
En síntesis, la idea del sometimiento del habitante rebelde mediante la conquista militar del territorio reclamado por la nación se corresponde lógicamente con la percepción política del habitante como 'salvaje' y del territorio como 'desierto' (NAVARRO FLORIA, 2001, p. 375).
}

Navarro Floria não pretende mostrar, assim como Quijada, o extermínio indígena pelo simples gosto sanguinário, mas, nessa atitude, o estabelecimento de uma política de integração hierarquizada (NAVARRO FLORIA, 2005, p. 35) que esperava do índio uma conversão religiosa, uma submissão pacífica, o respeito à ordem estatal e a realização de um trabalho produtivo (NAVARRO FLORIA, 2001, p. 350-351). Nesse ínterim, reafirmamos nossa perspectiva de que tal lugar interpretativo pouco avança 
para a compreensão da temática indígena, porque a trata como uma questão abstrata de cunho político, discutida, concretizada e enraizada institucionalmente. Essa visão não considera qualquer presença cotidiana e palpável do índio, e, assim, ao tratá-lo como mera escolha de uma cultura política argentina, ignora a presença de uma realidade inalienável que incomodava. Ao legar um espaço meramente político ao índio, confirmam-se os estereótipos criados pelo século XIX sobre a superação de uma identidade selvagem.

Os estudos desses três autores são bastante elucidativos para nossa reflexão sobre o espaço indígena na história argentina: ele parece ser considerado pela historiografia nos momentos em que se torna importante para corroborar o entendimento do discurso político produzido pelo século XIX. O índio é compreendido, portanto, a partir do olhar criollo, recuperado na medida em que ajuda a sinalizar as propostas dos intelectuais-políticos do século em questão, e não a partir das tensões que envolveriam a presença de grupos nativos durante a construção dos ideais nacionalistas. Tais perspectivas negam qualquer protagonismo ao indígena e não resolvem seu lugar nos discursos civilizacionais, uma vez que apenas indicam as formas como a sociedade argentina soluciona seu encalço indígena e, assim, define seu passado. Há nesses autores uma noção de produção histórica, mas como se toda ela estivesse declaradamente sob o controle político criollo.

\section{A busca por um novo lugar do indígena: indefinição histórica ou a- historicidade?}

Conforme apresentado na análise da pesquisadora Quijada, o surgimento dos estudos culturais abriu espaço para pensar a circulação da temática indígena no país, valorizando, em alguma medida, aspectos particulares da vida indígena no contato com a experiência republicana. Grande parte desses trabalhos dedica-se a um eixo metodológico que merece ser destacado: uma forte tendência a valorizar os estudos da micro-história, com ênfase especial nas premissas antropológicas de investigação. Esse terceiro viés argumentativo tenciona-se com os demais - o de vítima e o de derrotado — porque revela a preocupação de alcançar o “indígena em si”, que, até então, teria sido ignorado em sua participação efetiva no século independentista. Segundo essa vertente,

Revista Eletrônica da ANPHLAC, n.11, p. 105-140, jul./dez. 2011. http://revista.anphlac.org.br/index.php/revista 
os índios deveriam ser mais valorizados nos episódios de contato com tropas militares em luta pela conquista territorial.

Esses esforços para que o indígena obtivesse um espaço próprio de discussão na Argentina são bastante significativos. Com a disposição de romper as antigas ortodoxias que homogeneizavam e reduziam o trato ao elemento nativo (SABATO, 2001, p.42) à etnografia e à antropologia, recrutou-se uma perspectiva histórica, cujo objetivo seria avançar na caracterização temporal do indígena, recuperando os atores negligenciados e sua forma de agir (PALACIO, 2002, p. 38). Assim, a disciplina histórica dos anos 1980 unia-se às ciências sociais com a finalidade de dar voz ao indígena no século XIX, a fim de remover-lhe o estatuto de "ingênuo" e "passivo". Dentro dessa expectativa, que basicamente baliza o debate sobre o índio hoje, dois são os problemas que apontamos: no esforço de integrar os indígenas à história nacional, há uma transposição de valores criollos, decorrente de uma perspectiva a-histórica preocupada em redimensionar os significados do século XIX e não em questionar suas constituições discursivas; tampouco logra-se estabelecer ao índio um lugar histórico a que se propunha, quando se joga o debate para uma perspectiva indefinível ao reunir as mais diversas áreas das ciências humanas.

Dispondo de um olhar minucioso sobre as "organizações" das sociedades indígenas com a abertura para os estudos antropológicos (BURKE, 2005, p. 49), pesquisas como a de Sol Lanteri que defendem a multidisciplinaridade como corpo metodológico do trabalho historiográfico tornam-se recorrentes. O ponto central de um dos trabalhos da autora é a recuperação da importância dos agentes locais, tanto estancieiros quanto indígenas, na ocupação da região de Azul y Tapalqué na primeira metade do século XIX (LANTERI, 2006). Lanteri define seu trabalho como um estudo de caso ao focalizar as características do processo colonizador junto às articulações socioétnicas e políticas desenvolvidas especificamente na região de Azul, entendendo que a micro-história seria uma fuga importante às explicações unidirecionais e automáticas dadas, em geral, a todo o território nacional (2006, p. 7). Deste ponto de vista, a autora valoriza a participação ativa do indígena na conformação da sociedade e do Estado provincial-nacional:

Por cierto, el rescate de un nuevo agente en la campaña rioplatense desde la colonia tardía, el pequeño-mediano productor-propietario agrario o

Revista Eletrônica da ANPHLAC, n.11, p. 105-140, jul./dez. 2011. http://revista.anphlac.org.br/index.php/revista 
“campesino", generó nuevas preguntas y complejizó el panorama social, demográfico, económico, cultural y político de este espacio, que presentaba así su propia dinámica como contra-cara de la sociedad indígena con la que interactuó, junto con otros actores, hasta la unificación del Estado a finales del siglo XIX (LANTERI, 2006, p. 2).

Grande parte desse texto, exposto num congresso internacional de estudos latino-americanos realizado no Brasil, centraliza-se num debate metodológico que, apresentando problemáticas sobre fontes e abordagens de cunho político sobre a fronteira, propõe a reconstrução histórica e interdisciplinar como solução para melhor alcançar o índio nesse espaço dinâmico e complexo (LANTERI, 2006, p. 7). As informações etnográficas seriam fundamentais para compreender as autonomias indígenas devido a sua possibilidade de delinear traços específicos para cada grupo étnico, da mesma forma que seria de grande utilidade o aporte da arqueologia, que, com sua temporalidade muito mais abarcadora, ajudaria a visualizar melhor o indígena (LANTERI, 2006, p. 11-12). Entendemos a proposta da autora dentro de um desejo de definir o indígena histórico, pois, uma vez que os índios já teriam sido bastante estudados ao longo do século XX pelas ciências sociais, receberiam novas aberturas interpretativas nos anos 1980 a partir de um patamar pré-reconhecido cientificamente. ${ }^{14}$

A fim de melhor explorar essa interdisciplinaridade, podemos relacionar a postura de Lanteri aos propósitos da revista Tefros: Taller de Etnohistoria de la Frontera Sur, porque, além de a autora possuir inúmeros artigos ali publicados, este periódico exemplifica um esforço editorial crescente de reunir especialistas das mais diferentes áreas para debater a questão indígena, conforme explicitado na própria nota editorial da revista:

También pretendemos desarrollar la interdisciplinariedad propia de la Etnohistoria reuniendo a especialistas nacionales y extranjeros de todas las actividades del saber que contribuirán al conocimiento y la interpretación del espacio vital - físico, biológico, histórico, arqueológico y antropológico -

\footnotetext{
${ }^{14}$ É interessante destacar as observações feitas por Mandrini e Ortelli sobre os motivos de não existir um desenvolvimento crítico forte da antropologia na Argentina: a influência da Escola de Viena (Kulturkraise), que teria direcionado suas pesquisas em torno de motivos políticos e acadêmicos, parcamente científicos (p. 62-63). Eles apontam, no questionamento do determinismo geográfico, do tradicionalismo, com a introdução da história cultural, as grandes inovações teóricas (p. 64), que viriam reconfigurar o lugar da antropologia. Dessa forma, a proposta do artigo que escrevem estaria em estudar as populações indígenas sob essa nova perspectiva antropológica e, agora, histórica. MANDRINI, Raúl; ORTELLI, Sara. Una frontera permeable: los indígenas pampeanos y el mundo rioplatense en el siglo XVIII. In: GUTIÉRREZ, H; NAXARA, M; LOPES, M. Fronteiras, personagens, identidades. São Paulo: Olho D'Água, 2003.
}

Revista Eletrônica da ANPHLAC, n.11, p. 105-140, jul./dez. 2011. http://revista.anphlac.org.br/index.php/revista 
en el que se conjugaron las relaciones interétnicas a lo largo de la Gran Frontera Sur. Para cumplir con esa finalidad, el Taller pretende constituirse en un ámbito de interacción permanente, suficiente, necesaria y confiable como para hacer de la producción etnohistórica una rama del saber interdisciplinaria (LA DIRECCIÓN). ${ }^{15}$

É interessante notar que a etno-história parece consolidar-se como mecanismo central para os estudos indigenistas, tendência essa sentida em toda a América Latina, conforme podemos ver na grande divulgação da revista América Indígena — um periódico de origem mexicana estabelecido em parceria com diversos países do continente, incluindo a Argentina, com a finalidade de fomentar “(...) el intercambio de informaciones acerca de la vida indígena actual y de la política y programas que se están desarrollando en su favor" ${ }^{16}$

O que essas publicações nos sugerem é que, apesar dos esforços de realocar historicamente o indígena ao pensá-lo temporal e espacialmente no século XIX, permanece uma perspectiva a-histórica desse elemento nativo considerado como uma problemática do presente frente aos percalços do passado, em nome de um afã pouco crítico de reconstituir determinado grupo indígena.

Para Marta Bechis, importante nome argentino nos estudos etnográficos e envolvida nos mais variados projetos da área, sendo, inclusive, coordenadora acadêmica da revista Tefros, a etno-história seria fundamental para os estudos indigenistas porque retrataria os processos históricos de interação entre alteridades coletivas,

(...) en busca de teorías y metodologías que abran la percepción del investigador hacia abarcar una mayor amplitud temporal y una mayor profundidad en el estudio de los procesos históricos - que pueden cubrir meses o años - , procesos que son definidos por, a la vez que van definiendo a, las relaciones hegemónicas, hasta el episodio final que podemos ya conocer o todavía no (BECHIS, 2005, p. 1).

Para a autora, o valor dessa abordagem estaria em poder designar, com menor prejuízo, a história de povos sem Estado e em sua maioria ágrafos (BECHIS, 2006, p. 2).

\footnotetext{
${ }^{15}$ Nota da direção retirada do site: <www.tefros.com.ar/revista/v1n1p03/objetivos.htm>

16 Trecho retirado da apresentação da revista junto aos membros diretivos dela constituintes. Referência editorial: América Indígena. Instituto Indigenista Interamericano, Insurgentes Sur n. 1.690, Colonia Florida, Mexico 20, D. F.
}

Revista Eletrônica da ANPHLAC, n.11, p. 105-140, jul./dez. 2011. http://revista.anphlac.org.br/index.php/revista 
Em sua pesquisa sobre as tribos pampeanas, Bechis demonstra que a afirmação da autoridade nacional e o surgimento do homem de fronteiras não teriam acontecido sem a oposição indígena (2006, p. 22), construindo tal intento a partir de apontamentos que serviriam tanto para análises históricas como antropológicas. Valendo-se de documentações primárias baseadas em cartas de caciques, relatos de comandantes fronteiriços e narrações de testemunhas oculares, Bechis revelaria que as noções de Estado, nação e território, por ela chamadas de criollismos, eram pouco precisas entre os próprios criollos e, por isso, manteriam uma expressão segura na relação com o índio, já que expressavam uma realidade que se sabia em construção (2006, p. 6). Dessa forma, o indígena ganharia significativa importância no republicanismo argentino, sendo responsável pela consignação dos conceitos-chave de formação político-cultural da sociedade argentina, tendo exercido certa independência nas negociações de alianças e de acordos territoriais (BECHIS, 2006, p. 9).

Os dois movimentos de análise propostos pela autora a partir de uma perspectiva etnológica - inserir o protagonismo indígena na sociedade oitocentista e, consequentemente, reavaliar os debates e os personagens políticos formadores da nação argentina - geram uma problemática imediata para o campo da história: o teleologismo, conceito que identifica a ressignificação dos fatos históricos segundo perspectivas enunciadoras do presente. Por exemplo, quando indica que a linguagem desprendida dos Tratados de Paz estabelecidos entre criollos e índios seria fundamental para compreender a formação do pensamento político, a autora deposita os motivos nacionalistas criollos como parte do domínio simbólico indígena, reduzindo a temporalidade de conceitos como "nação" a uma base factual. Segundo a observação cautelosa de Palti, seria preciso mudar a discussão de conteúdos ideais, entendidos como a consagração da modernidade, da civilização, como fỉm único a todos os personagens políticos heterogêneos do século XIX, inserindo "los nucleos problemáticos alrededor de los cuales se desplegaría el debate político" (PALTI p. 253). Dessa forma, ponderamos que o estudo de povos sem Estado, a partir de uma comparação com a sociedade institucionalizada oitocentista, impossibilitaria o estabelecimento de um debate histórico.

Embora seja crucial para os dias de hoje reavaliar o lugar do indígena na historiografia argentina, não será concedendo-lhe um papel na tradicional forma de 
encarar a política advinda desde o século XIX até a atualidade que se fará possível dimensionar a sua importância historicamente. Nesse sentido, nosso questionamento abrange os estudos arqueológicos relacionados aos esforços etnográficos no país, requisitados pelo anseio de "fazer aparecer" um ente esquecido pelo tempo. Inúmeros são os trabalhos que se fundam em premissas arqueológicas de análise, mas, para nosso objetivo, apontamos duas perspectivas adotadas para o caso indígena: a possibilidade de alcançar um registro longínquo do tempo e, por outro lado, a capacidade de tornar mais palpável uma realidade desconhecida, materializando a vivência indígena na sociedade argentina.

Um exemplo intrigante aparece na organização dos onze tombos da coleção Nueva Historia Argentina, cujo objetivo seria o de contemplar a totalidade dos temas vividos nesse território conhecido como "Argentina", retratando desde os povos originários até a ditadura dos anos 1970, incluindo, ao final, um atlas histórico. No primeiro volume, intitulado "Los pueblos originarios y la conquista", que visa enunciar o período pré-colombiano argentino, os artigos compilados ficaram a cargo exclusivo de arqueólogos porque, segundo a apresentação de Myrian Tarragó, a intenção seria a de "mostrar" o indígena àqueles que o desconheciam (TARRAGÓ, 2000, p. 13). Para a estudiosa, a Conquista do Deserto seria tanto uma necessidade de legitimação da ocupação territorial quanto uma amostra do desconhecimento da existência de povos originários no território nacional. A pretensão dessa abordagem seria reavaliar os motivos que levaram ao esquecimento de tal elemento nativo, indicando vir da própria postura indígena da região platina a falta de enraizamento de culturas autóctones no mundo criollo, pois diferentemente

(...) de otros Estados, como México y Perú, donde el aporte indígena fue tan fuerte y evidente, que fue utilizado como aspecto primordial y fundacional del sentido nacional. Esta falencia ha producido consecuencias no deseadas en la educación y en la valorización de nuestro patrimonio nacional (TARRAGÓ, 2000, p. 11).

Novamente, o enfoque delimitador da questão indígena está na perpetuação de um pensamento criollo constituído no século XIX, postura esta que, ao invés de analisar o ato de enaltecer ou obliterar a imagem do índio na construção da identidade nacional, considera o pré-estabelecimento cultural de cada território como responsável pela 
atitude de seus sucessores. Dessa forma, o papel da coleção seria o de descrever a presença indígena restrita a uma remota temporalidade, já que nos tomos seguintes a república toma seu posto e assume a direção da história do país, fazendo desaparecer o índio. A arqueologia garante, através da descrição, a presença de outra cultura não vivenciada no país, proporcionando uma aura a-histórica a um personagem que pode ser constatado, mas não valorizado. ${ }^{17}$

Com essa crítica não queremos negar a possibilidade e a importância de realizar estudos antropológicos e arqueológicos sobre o indígena, pois a abrangência alcançada por tais pesquisas torna possível revisitar argumentos estanques e significá-los dentro de uma nova ordem discursiva e interpretativa. O que pretendemos questionar, portanto, não é a positividade de tais reflexões, mas a atribuição que elas podem estabelecer à temporalidade indígena, ao passo que cobram resoluções de uma problemática social na reverência da atual sociedade argentina. Essa postura a-histórica manteria sedimentadas as categorias oitocentistas como estrutura social, política e intelecto-cultural da Argentina, as mesmas que desejamos, pois, contextualizar e ampliar.

A própria historiadora Quijada, com a qual trabalhamos anteriormente neste texto, também se encaixa no questionamento quanto ao trato temporal do índio, o que mostra que os autores podem transitar entre as diversas perspectivas apresentadas. Em artigo que pretende tornar fluidas as fronteiras internas vivenciadas durante as experiências de constituição do país - Repensando la frontera sur argentina: concepto, contenido, continuidades y descontinuidades de una realidade espacial y étnica (siglos XVIII-XIX) -, Quijada procura incluir o índio na construção histórica e processual dos conceitos fronteiriços enraizados pela história argentina, defendendo a anulação das perspectivas que valorizem um personagem em detrimento de outro, a saber, a sociedade majoritária ou os indígenas (QUIJADA, 2002, p. 109). Sua proposta estaria na introdução do indígena no debate historiográfico, gerando uma homogeneização discursiva a temáticas opositoras, porque, ao entender a ausência indígena como uma construção histórica, a autora reafirmaria as bases criollas de explicação.

\footnotetext{
${ }^{17}$ A nossa crítica constituiu-se a partir das ideias de De Certeau, para o qual o ato de fazer história não configuraria um ato descritivo. DE CERTEAU, Michel. A escrita da história. Rio de Janeiro: Forense Universitária, 2006. p. 33.
} 
En este marco general, es importante no olvidar que, al contrario de lo que afirma cierta literatura indigenista según la cual la violencia en la frontera es sobre todo una forma de reacción indígena ante los atropellos de los europeos o criollos, las dos acciones de los indios que más afectaron las relaciones con la sociedad blanca, es decir, el saqueo y el cautiverio, no se originaron en los enfrentamientos entre europeos y nativos sino que formaban parte de las culturas indígenas y de las relaciones intertribales desde mucho antes de que se produjera dicho choque. La práctica del cautiverio, por ejemplo, era una costumbre muy antigua de cuya existencia hay noticias que se remontan tanto al período incaico como a los primeros años posteriores a la conquista (...) (QUIJADA, 2002, p. 112).

Ao ampliar o quadro geral dos processos históricos argentinos, a autora vale-se das mesmas categorias de análises até então utilizadas no estudo do universo criollo para alcançar as sociedades indígenas, sem reconstruir ou reavaliar o conteúdo pragmático conceitual de uma ordem criolla por excelência. Nesse sentido, igualar-seiam as proposições entre índios e criollos nos embates oitocentistas, definindo, por exemplo, que ambos estariam envoltos por uma mesma motivação comercial, revelando interesses correspondentes de pacificação na manutenção do intercâmbio fronteiriço de produtos (QUIJADA, 2002, p. 114-115). Quijada não pressupõe interpretações díspares a um mesmo evento, mas vontades equânimes que garantiriam, assim, historicidade ao indígena.

Essa tendência argumentativa pode ser encontrada até mesmo na análise apresentada em Indígenas e criollos: política, guerra e traição nas lutas no sul da Argentina (1852-1885), do historiador Gabriel Passetti, que, embora busque um olhar mais histórico no alcance do mundo indígena, sendo particularmente crítico ao trabalho etnográfico realizado por Quijada, não se desvincula dessas atribuições criollas ao universo simbólico indígena (PASSETTI, 2005, p.14). O conteúdo desse trabalho, que constitui novamente uma visão estrangeira sobre a história argentina, despertou nosso interesse porque registra uma abordagem militar e política a partir de um novo viés historiográfico, com o objetivo de mapear e compreender a ação indígena no século XIX. Em nota introdutória, o autor define sua atividade histórica como uma "história política renovada", que incluiria não só o uso de uma documentação oficial diferenciada - cartas de caciques às tropas do exército nacional e tratados de alianças realizados entre ambos - mas também certos cuidados historiográficos que ultrapassariam as explicações dualistas de "vítima e algoz", "manipulado e manipulador", "bárbaro e civilizado" (PASSETTI, 2005, p. 10). 
Buscando analisar os indígenas como agentes ativos da ocupação territorial no século XIX e, portanto, como formadores da nação, Passetti também tencionaria desarticular uma historiografia deliberatória da ingenuidade indígena, apontando as ações e os interesses dos caciques como vontades determinantes nesses combates, ou seja, dando voz e ação aos até então considerados mudos e passivos no processo de ocupação sulina (PASSETTI, 2005, p. 18). No entanto, sua abordagem, preocupada com as estratégias militares baseadas em tratados estabelecidos entre as tropas do governo e as tribos nativas, acaba depositando valores criollos nas vontades guerreiras dos indígenas. Afirmar que estes também tinham interesses de modernidade (PASSETTI, 2005, p. 67), como alternativa para revisar seus papéis nos anos finais em que se concretiza a Conquista do Deserto, não estabelece novos parâmetros para entendermos a posição desses grupos nativos. Ao elencar documentação oficial em seu embasamento teórico, Passetti percebe a forte presença física desses indígenas, o que não implica uma apreensão do envolvimento da sociedade criolla com os índios na formação do imaginário social argentino, marcado mais forte e decisivamente pela própria ausência dessa cultura na memória histórica do país.

Vários seriam os trabalhos, ainda a ser indicados, que se encaixariam nessa linha argumentativa de transposição de valores criollos, tendo em vista que atualmente se trata de um dos principais formatos que assumem o debate sobre o índio na Argentina. ${ }^{18}$ É importante notarmos que, embora se valham de uma perspectiva sociocultural, tais estudos, ao nortearem as pesquisas para a concretização de um resgate histórico, revelam um diálogo político com o presente no qual enunciam seus debates, tornando latentes as premissas de uma memória histórica criolla oitocentista naturalizada como identidade argentina. Mais uma vez podemos, então, apontar que o indígena seria uma temática desenvolvida sem valor histórico em si, todavia recorrente devido à abertura que proporciona novas entradas na problemática de enunciação política no país. Dessa

\footnotetext{
${ }^{18}$ Vários seriam os exemplos: TERUEL, Ana. Misiones, economía y sociedad: la frontera chaqueña del noroeste argentino en el siglo XIX. Buenos Aires: Univ. Nacional de Quilmas, 2005; HERNANDEZ, Isabel. Identidad indígena y educación. Desarrollo Económico, v. 28, n. 109; NACACH, Gabriela. Tan vivos, tan muertos. Dos décadas de representaciones y carácter de la frontera pampeana: entre Lucio V. Mansilla (1870) y Estanislao Zeballos (1880). Boletín Tefros, v.4 n. 2, 2006; OLMECO, Ernesto. El "silencio militar" en la frontera del río cuarto a mediados del siglo XIX: una clave para comprender el conflicto. Boletín Tefros, v.4 n. 2, 2006; NICOLETTI, María A. "La Congregación Salesiana en la Patagonia: "civilizar", educar y evangelizar a los indígenas (1880-1934)". In: Estudios interdisciplinarios de América Lattina y Caribe, v.15, $\mathrm{n}^{\circ}$ 2; entre inúmeros outros.
}

Revista Eletrônica da ANPHLAC, n.11, p. 105-140, jul./dez. 2011. http://revista.anphlac.org.br/index.php/revista 
forma, o trato aos indígenas não se consagraria sob um patamar revisionista da historiografia, pois tal perspectiva reafirma, neles, o estatuto de ingenuidade, ao rematar, por exemplo, que, embora a formação do Estado nacional tenha influenciado as sociedades indígenas, teria sido também por empenho delas próprias que se deu o "recebimento" da cultura criolla (BECHIS, 2006, p. 21-22).

\section{A literatura como proposta: o indígena e o regate de sua historicidade}

A partir do breve mapeamento e da problematização dessas três constatações a respeito do indígena vítima, derrotado e/ou a-histórico, nossa análise histórica tornou-se passível da própria indefinição sobre o lugar indígena e os meandros argumentativos dessa historiografia argentina. Perceber a manutenção de um discurso histórico pautado numa problemática fundamentalmente política nos levou a refletir sobre as fontes utilizadas em tais investigações e sobre a perspectiva a qual estaria submetida essa documentação agregadora do universo indígena, particularmente oficial e envolta por uma tradição liberal. ${ }^{19}$

Este estudo foi bastante importante para o desenvolvimento de um novo olhar sobre a representação indígena porque, ao adentrarmos o tema, acreditávamos estar em busca de uma imagem do índio circunscrita ao período da independência do país; no entanto, percebemos que tanto o século XIX quanto o XX e o XXI mantiveram o discurso segregacionista em relação ao nativo. A única existência do indígena para a história argentina parece resumir-se aos trâmites políticos de formação do país, seja através da valorização do olhar criollo para justificar a dominação e subjugação daquele, seja a partir da própria ação indígena limitada aos diálogos fronteiriços. Dessa forma, o questionamento aqui proposto, evidentemente de ordem teórica, pretende capturar a imagem do índio na literatura, a fim de delinear uma nova espacialidade à temática e buscar novos diálogos.

\footnotetext{
${ }^{19}$ Não estamos generalizando tal proposição nos estudos aqui apresentados, mesmo porque alguns nomes como Viñas, Montaldo e Shumway valem-se de documentos literários do século XIX em suas análises, ainda que sejam lidos como documentos políticos da época. Nos trabalhos de Quijada, Navarro e Passetti a base das pesquisas são fontes de arquivos como diários de sessões, cartas oficiais, censos, inventários, tratados de paz, entre outros. Envoltos por uma tradição liberal, tais documentos frisam certa linearidade política no constructo histórico do país, evocando a predominância de discursos criollos, elitistas, oficiais, como supostos definidores da memória nacional.
}

Revista Eletrônica da ANPHLAC, n.11, p. 105-140, jul./dez. 2011. http://revista.anphlac.org.br/index.php/revista 
Tal proposição não implica o abandono da noção política, pois, conforme apresentamos ao longo do artigo, esse é o motivo que fomenta a problemática histórica do país. O objetivo é ampliar o debate explorando a literatura oitocentista como fonte importante para o estudo sobre os índios, e, assim, indicar que a problemática a eles atribuída até os dias de hoje, nos mais diversos momentos historiográficos, teria surgido de uma lógica histórica datada em que se criavam tanto as noções de política quanto de cultura local. Pretendemos assinalar, como nos sugere Edward Said, que restringir o histórico cultural da nação — neste caso, a crença da ausência indígena ou a consagração de sua nulidade cultural ao país - ao teatro das causas políticas e ideológicas vividas no século XIX resulta no problema da veneração da própria cultura supondo-a divorciada do mundo cotidiano.

\footnotetext{
Muitos humanistas de profissão são, em virtude disso, incapazes de estabelecer a conexão entre, de um lado, a longa e sórdida crueldade de práticas como a escravidão, a opressão racial e colonialista, o domínio imperial e, de outro, a poesia, a ficção e a filosofia da sociedade que adota tais práticas (SAID, 1995, p. 14).
}

Sob essa perspectiva, a literatura possibilita pensar o momento cultural em que estavam submersos políticos e intelectuais na constituição dos projetos nacionais pósindependentistas, oferecendo espacialidade ao elemento indígena como um dos personagens do cenário argentino oitocentista, além de revelar uma problemática político-cultural que pode ser observada nas elaborações estéticas dos discursos produzidos no período. Analisar o indígena historicamente é, inclusive, perceber os motivos que fizeram com que a mesma caracterização dele persistisse ao longo dos séculos, levando em conta que o ato de selecionar certa memória nacional pressupõe o ato de imaginar determinado passado condizente com a realidade política vivida, e que construções identitárias devem ser encaradas como fórmulas em cuja autenticidade e veracidade seus articuladores confiavam (AMBRANSON, 1999, p. 347).

Segundo Ana Pizarro, literatura e política relacionavam-se no século XIX sob a mesma vontade de projeto nacional, ambas consistindo em estabelecer uma organização para a sociedade. Por isso, muitas vezes, podemos encontrar polêmicas em torno da língua e da cultura nos próprios discursos políticos (PIZARRO, 1994, p. 24-25). Nesse sentido, a homogeneização da representação política e cultural obtém um aspecto 
criativo que interferiria diretamente no real, apresentando uma concomitância entre realidade e imaginação (THEODORO, 1992, p. 10). Se considerarmos a proposição de que memória e imaginação pautam-se num mesmo princípio organizativo (MITRE, 2003, p. 13), pois ambas apresentariam a ideia de unidade e continuidade entre o sujeito e sua experiência, veremos que a "realidade" entre os intelectuais do século XIX pode ser o reflexo das peculiaridades de um país em formação. Os esquecimentos constitutivos em torno da memória nacional, ou seja, a capacidade de criar vazios num recontar histórico (MITRE, 2003, p. 11), podem ser campos bastante elucidativos para nossa interpretação dos discursos político-literários da Argentina.

Em geral, dada importância é pertinente apenas aos estudos sobre a adoção do indígena como símbolo nacional. Ou seja, essa imagem parece só adquirir relevância teórica nos casos em que as heranças culturais nativas são explícitas, como no México, na antiga Nova Espanha ou no Alto Peru. O nosso esforço está em mostrar que, mesmo não sendo adotado necessariamente como símbolo argentino, o indígena possui significativa importância para a organização e as definições políticas e culturais que compõem a constituição identitária argentina. Ambos os autores destacados apresentam em suas obras uma definição própria de "memória".

Nesse sentido, a literatura gauchesca - gênero através do qual se travaparte significativa dos debates político-culturais da sociedade argentina criolla ao longo do século XIX - foi praticamente ignorada em seu valor nos estudos concernentes às questões indígenas e, por isso, se nos apresenta como um campo fecundo a ser explorado. Embora relacionada imediata e aleatoriamente aos desígnios políticos de intelectuais citadinos que buscariam revelar através da voz gaucha seus posicionamentos $^{20}$, a gauchesca é um gênero literário sobrevivente entre os argentinos por suas características populares na forma escrita, o que abre espaço a distintas leituras, significados e constructos históricos, revelando nessa abertura dialógica os debates políticos conformadores do incipiente cenário público oitocentista. ${ }^{21}$ Esse tipo de fonte

\footnotetext{
${ }^{20}$ Conforme esteve fortemente em pauta no início do século XX e referenciada na renomada obra de Jorge Luis Borges El Martín Fierro de 1953, escrito com a colaboração de Margarita Guerrero. Para a síntese das transformações do gênero e de seu personagem mais afamado, ver: VERDEVOYE, Paul. La identidad nacional y el Martín Fierro. In: HERNÁNDEZ, José. Martín Fierro - Edición crítica. Coords. Élida Lois y Ángel Nuñez Barcelona: SPICIONE, 2001.

${ }^{21}$ Consideramos o gênero gauchesco como "sobrevivente" por poder ser, ainda hoje, recuperado como um lugar recorrente de determinado tipo de debate que, embora tenha perdido grande parte de sua força argumentativa, uma vez que sua fórmula corresponde a uma necessidade de debate imposto pela
} 
possibilita, portanto, repensar o desaparecimento do índio na abordagem da própria história argentina, pois, ainda que seja real seu desvanecimento histórico e inquestionável a pouca importância cultural que recebe nessa sociedade, em cada obra do gênero notamos o elemento indígena caracterizado ao lado do gaucho, sendo este o protagonista por excelência. Essa observação nos leva a pensar a conduta da sociedade criolla em relação ao indígena mediante a necessidade por parte dos intelectuaispolíticos de construir essa ausência do elemento nativo. Tal perspectiva nos convida a considerar os aspectos da sociedade criolla para além de sua atitude marcadamente política, estabelecendo um intenso diálogo entre as instituições sociopolíticas e o universo simbólico local, que, juntos, envolveriam e formariam os quadros de funcionamento social do novo país (PRADO, 2004, p. 22).

Ao inserir uma lógica de pensamento que designa a caracterização tanto do índio quanto do gaucho, a literatura gauchesca nos permite suplantar uma recorrente tradição liberal argentina que, muitas vezes, identifica o discurso criollo como homogêneo ao longo do século XIX, e, sobretudo, acaba por naturalizá-lo como símbolo nacional. O esforço de desconstrução indígena a favor do gaucho é parte desse pensamento oitocentista, e pretende frisar a existência de uma Argentina que sabia fazer-se, concretizar-se. Ora, aceitar como tal a herança da ação criolla é não reconhecer os artífices desse debate.

Daí, considerarmos o indígena como parte da lógica de produção desses discursos, de forma a inserir o debate por caminhos menos enviesados de análise. Se destacar o indígena da conformação do pensamento nacional para estudá-lo implica reiterar uma ideia de manipulação cultural em prol de uma cultura homogênea e branca, conforme questionamos nos mais diversos estudos apresentados anteriormente, propomos, então, observar os discursos sobre o índio concomitante ao produzido sobre o gaucho na literatura gauchesca. Assim, ao tomá-los dentro de uma problemática maior

sociedade oitocentista em constantes choques políticos e culturais, sua plasticidade serve como meio de denúncias sociais da vida da população. O gênero faz-se presente nas músicas de León Gieco e Atahualpa Yupanqui (sucessos respectivos com Bandidos Rurales, 2001, e Coplas del payador perseguido, 1972), nos quadrinhos de Roberto Fontanarrosa (Inodoro Pereyra, el renegao, 1972), no filme de Leonardo Favio (Juan Moreira, 1972), entre inúmeras outras manifestações culturais. Sobre a literatura gauchesca, ver: RAMA, Ángel. El sistema literario de la poesía gauchesca. In: RIVERA, Jorge B. (Coord.). Poesia gauchesca. Caracas: Biblioteca Ayacucho, 1977. p. IX - LIII; LUDMER, Josefina. El género gauchesco. Un tratado sobre la pátria. Buenos Aires: Sudamericana, 1988; ROMANO, Eduardo. Sobre poesía popular Argentina. Buenos Aires: CEAL, 1983.

Revista Eletrônica da ANPHLAC, n.11, p. 105-140, jul./dez. 2011. http://revista.anphlac.org.br/index.php/revista 
— como a construção dos espaços de barbárie mediante a necessidade de formação do pensamento nacional civilizado - , lograríamos deslocar o foco de índio vitimado, derrotado ou incapacitado para o de personagem no processo de construção políticocultural, mesmo que fosse através da sua ausência.

\section{Bibliografia}

AMBRANSON, Pierre-Luc. Las utopias sociales em América Latina en el siglo XIX. México: FCE, 1999.

BECHIS, M. La 'organización nacional' y las tribus pampeanas en argentina durante el siglo XIX. Boletín Tefros, v. 4, n. 2, 2006. Disponível em:< http://www.tefros.com.ar/revista/v4n2p06/paquetes/bechis.pdf>. Acesso em: 15 maio 2011.

BECHIS, Marta. La teoría de juegos-drama en la etnohistoria. Boletín Tefros, v. 3, n. 1, 2005. Disponível

em:

<http://www.unrc.edu.ar/publicar/tefros/revista/v3n1p05/completos/juegosdrama.pdf $>$. Acesso em: 15 maio 2011.

BURKE, Peter. O que é história cultural? Rio de Janeiro: Jorge Zahar Ed., 2005.

DE CERTEAU, Michel. A escrita da história. Rio de Janeiro: Forense Universitária, 2006 .

DONGHI, Tulio Halperin. (1980). Proyecto y construcción de una nación (1846-1880). Buenos Aires: Ariel Historia, 1995.

FLORIA, Carlos Alberto; BELSUNCE, Antonio García. Historia política de la Argentina contemporánea (1880-1983). Madrid: Alianza Editorial, 1988.

GUERRA, François-Xavier. Las mutaciones de la identidad en la América Hispánica. In: GUERRA, F. (Coord.) Inventando la nación. México: FCE, 2003.

HORA, Roy; TRIMBOLI, Javier. Pensar la Argentina. Los historiadores hablan de historia y política. Buenos Aires: El Cielo por Asalto, 1994.

LANTERI, Sol. La frontera sur pampeana durante la época de Rosas. Entre el comportamiento de los agentes y la reconstrucción interdisciplinaria (Azul y Tapalqué, Buenos Aires, Argentina, primera mitad del siglo XIX). 2006. Disponível em:

Revista Eletrônica da ANPHLAC, n.11, p. 105-140, jul./dez. 2011. http://revista.anphlac.org.br/index.php/revista 
<http://www.anphlac.org/periodicos/anais/encontro7/lanteri_sol.pdf >. Acesso em: 15 maio 2011.

MITRE, Antonio. O dilema de centauro: ensaios de teoria da história e pensamento latino-americano. Belo Horizonte: Ed. UFMG, 2003.

MONTALDO, Graciela. Ficciones culturales y fábulas de identidades América Latina. Argentina: Beatriz Viterbo Editora, 2004.

MONTEIRO, John M. Tupis, tapuias e historiadores. Estudos de História Indígena e do Indigenismo. 2001. Tese (Livre docência em Etnologia) — Universidade Estadual de Campinas (Unicamp), Campinas, 2001.

NAVARRO FLORIA, Pedro. El 'salvaje' y su tratamiento en el discurso político argentino sobre la frontera sur, 1853 - 1879. Revista de Indias, v. LXI, n. 222, 2001.

NAVARRO FLORIA, P.; ROULET, Florencia. De soberanos externos a rebeldes internos: la domesticación discursiva y legal de la cuestión indígena en el tránsito del siglo XVIII al XX. Boletín Tefros, 2005. Disponível em: <http://www.unrc.edu.ar/publicar/tefros/revista/v3n1p05/completos/soberanosext.pdf>. Acesso em: 15 maio 2011.

PALACIO, Juan Manuel. Una deriva necesaria: notas sobre la historiografía argentina de las últimas décadas. Punto de Vista, n.74, dic. 2002.

PALTI, Elias. El tiempo de la política. Buenos Aires: Siglo XXI, 2006.

PASSETTI, Gabriel. Indígenas e criollos: política, guerra e traição nas lutas no sul da Argentina (1852-1885). 2005. Dissertação (Mestrado), História, FFLCH-USP, São Paulo, 2005.

PIZARRO, Ana. La emancipación del discurso. In: PAZARRO, A. (Org.). América Latina: palavra, literatura e cultura. Campinas: Ed. Unicamp, 1994.

PRADO, Maria Lígia Coelho. América Latina no século XIX: tela, tramas e textos. São Paulo: Edusp, 2004.

PRATT, Mary Louise. Os olhos do império: relatos de viagem e transculturação. São Paulo: EDUSC, 1999.

QUIJADA, Mónica ¿Qué nación? Dinámicas y dicotomías de la nación en el imaginario hispanoamericano. In: GUERRA, François-Xavier (Coord.). Inventando la nación. México: FCE, 2003.

Revista Eletrônica da ANPHLAC, n.11, p. 105-140, jul./dez. 2011. http://revista.anphlac.org.br/index.php/revista 
Repensando la frontera sur argentina: concepto, contenido, continuidades y descontinuidades de una realidade espacial y étnica (siglos XVIII-XIX). Revista de Indias, v. LXII, n. 224, 2002.

. De mitos nacionales, definiciones cívicas, y clasificaciones grupales. Los indígenas en la construcción nacional argentina, siglos XIX a XXI. In: ANSALDI, Waldo (Coord.). Calidoscopio latinoamericano: imágenes históricas para un debate vigente. Buenos Aires: Ariel, 2004.

Nación y territorio: la dimensión simbólica del espacio en la construcción nacional argentina, siglo XIX. Revista de Indias, v. LX, n. 219, 2000.

ROMERO, José Luis. (1976). América Latina: a cidade e as ideias. Rio de Janeiro: UFRJ, 2004.

SABATO, Hilda. La historia en fragmentos: fragmentos para una historia. Punto de Vista. n. 70, agosto 2001.

SARLO, Beatriz. Paisagens imaginárias. São Paulo: Edusp, 2005.

SHUMWAY, Nicolás. (1991). La invención de la Argentina: historia de una idea. Buenos Aires: Emecé, 1995.

TARRAGÓ, Myrian (Coord.). Nueva historia argentina. Los pueblos originarios y la conquista. Buenos Aires: Ed. Sudamericana, 2000.

THEODORO, Janice. América barroca: tema e variações. São Paulo: Edusp, 1992.

TRILLO, Mauricio Tenorio. Argucias de la historia: siglo XIX, cultura y América Latina. México: Ed. Paidós, 1999.

VIÑAS, David. Indios, ejército y fronteras. Buenos Aires: Siglo XXI Ed., 1982.

Revista Eletrônica da ANPHLAC, n.11, p. 105-140, jul./dez. 2011. http://revista.anphlac.org.br/index.php/revista 